\title{
The Implementation of Learning Materials Based on Local Wisdom of Agricultural in Binjai to Improve the Students Problem Solving Abilities
}

\author{
Findi Septiani $^{1}$, Siti Sriyati ${ }^{2}$, Amprasto $^{3}$ \\ \{findiseptiani@gmail.com ${ }^{1}$ \}
}

Universitas Pendidikan Indonesia ${ }^{1,2,3}$

\begin{abstract}
The aim of the study was to measure the effectiveness of learning materials based on local wisdom of agriculture in Binjai in improving the students' problem-solving abilities. The research method was a quasi-experimental. The sample of study were students that consisted of experiment group which used learning materials based on local wisdom of agriculture in Binjai and control group that used student handbooks. Learning materials were tested by material experts and technology experts to ensure the quality of learning materials. The results showed that the learning materials based on local wisdom of agriculture in Binjai effective in improving students' problem-solving abilities in the experimental group students based on the results of $\mathrm{N}$ gain value were 0.67 which has medium criteria. It means learning materials based on agricultural local wisdom of agriculture in Binjai can be used as one of the learning materials in learning activities.
\end{abstract}

Keywords: Local wisdom, learning materials, effectiveness, problem-solving abilities

\section{Introduction}

Education is used as a pawn to create people of character. With this goal in mind, UNESCO in 1977 launched environmental education into the school curriculum which aimed to develop student awareness and concern for environmental problems. This environmental awareness is in line with environmental literacy which is used as a skill framework that must be possessed in the 21 st century [1].

Related to the need to increase environmental literacy, environmental problems require concrete solutions to overcome these problems. A learning approach is needed to stimulate students' high-level thinking in real-world problem-oriented situations, according to [2] that problem solving is one of the abilities students need in assessing real-life problems, especially environmental problems. The lecture process needs to be adjusted to the learning that can foster the required competencies in the knowledge age. Learning in question is a lesson that gives to the students the empowerment of its metacognitive ability, namely in the form of problemsolving and critical thinking [3].

Problem-solving skills were explicitly emphasized in the curriculum that is, as a basic competency that must be developed and integrated into a number of appropriate material [4], so 
that problem-solving skills were seen as important as the demands of learning outcomes for high school graduates in the knowledge age in this globalization era.

One strategy that can be done to explore the problem-solving ability among students is to carry out biological contextual learning and based on local contexts. Learning must involve students actively and use the environment as a learning resource. Raising local context in learning will increase students' understanding in understanding material and increase their concern for nature [5] where this caring attitude will affect environmental preservation and support the formation of knowledge, values, attitudes, and skills in decision making and problem-solving [6].

Syafii [7] states that students' learning outcomes were more focused on cognitive ability rather than the process. In some schools, the teachers even ignore some of the competencybased contents provided in the textbook and less attention is given to problem-solving skills. Teachers were still unable to create a lesson that could actively involve students in the learning process.

To achieve success in learning on ecosystem material and environmental change, a learning material is needed that can facilitate students in receiving lessons, namely by applying learning materials based on local wisdom that was oriented towards improving student problem-solving ability. Learning materials must be innovative and include local wisdom and local cultures so that they can provide students with real experiences to create contextual learning [8].

One region that is still closely related to its local culture is Binjai. The people in Binjai were the society that adheres to a hereditary tradition in maintaining local culture. The local culture of Binjai that is still maintained is in the process of managing agriculture. The management of agriculture with local wisdom aims to preserve the environment.

Agriculture in Binjai, not only processed by organically, but also has a variety of local wisdom, including Turun tanam, Menukal, Pengeboman, Mengemping padi, and Tutup panen. Turun tanam is the soil management technique that begins with prayers by farmers, then the soil is hoped and stepped on. Menukal is an agricultural management by utilizing the remains of straw which were used as the main ingredient of insect repellents in the fields. This activity plays a major role in maintaining the balance of the ecosystem because it can minimize the use of chemical-based pesticides. In addition to the use of straw, Pengeboman is also one way to eradicate rats using sulfur which is burned and fired directly into the nest of a rat under the ground with bamboo. This activity can preserve the environment because the rat will die in the hole without polluting the environment. Post-harvest, farmers have a tradition of threshing rice using legs which were carried out in a row at one of the residents' houses, this activity is called Tutup panen. Traditional ceremonies such as Upah-upah were also carried out by farmers by praying to God for blessings on their agricultural products. Also, there is also a tradition that is carried out once a year as a hereditary tradition that is welcomed enthusiastically by the Binjai people, Mengemping padi, is the tradition of processing rice which is pounded and shaped like a chip.

Agricultural management with local wisdom in Binjai was integrated into learning materials on ecosystem material and environmental change. Thus, in addition to improving student problem-solving ability, learning materials based on local wisdom can also be used as an effort to instill student responsibility and concern for the environment. This study aims to determine the effectiveness of the application of learning materials based on local wisdom in agriculture in Binjai in improving student problem-solving ability. 


\section{Method}

This study used a quasi-experiment using a non-equivalent control group design. In the implementation of learning materials implemented in class $X$ students in one of the High Schools in Binjai. Schools were chosen using the purposive sampling method, where schools were chosen based on certain considerations. School selection was done based on the location of the school which is close to the agricultural area in Binjai. Next, two classes were selected using the simple random sampling method, which was used as an implementation of learning materials based on local agricultural wisdom in Binjai as an experimental group, and a control group whose learning used Biology textbooks for class $\mathrm{X}$ for SMA /MA. Table 1 was an overview of the structure of the non-equivalent group control design.

Table 1. The Structure of the Non-Equivalent Control Group Design.

\begin{tabular}{llll}
\hline Group & Pretest & Treatment & Posttest \\
\hline Experiment & $\mathrm{O}_{1}$ & $\mathrm{X}_{1}$ & $\mathrm{O}_{2}$ \\
Control & $\mathrm{O}_{1}$ & $\mathrm{X}_{2}$ & $\mathrm{O}_{2}$ \\
\hline
\end{tabular}

Students' problem-solving ability was measured using a written test in the form of essay questions. The questions made include the problem-solving component, namely the formulate the problem, examine the problem, formulate hypotheses, problem-solving efforts, and evaluation. These questions about the ability of problem-solving were used in the implementation of the pretest and posttest for the experimental and control groups.

The learning materials based on local wisdom of agriculture in Binjai were tested for material validity and technology by expert lecturers. The test used for the validity of learning materials was a questionnaire statement.

Based on the results of the validation, the average score of learning material assessment by material experts obtained $78.18 \%$ in feasible criteria, so this learning material can be tested for research. In addition to the feasibility of learning materials tested by material experts, the learning materials were also tested for feasibility by the technology expert lecturers. The results of the validation by the technologist lecturer indicate that the average score of the learning material assessment was $92.26 \%$ in very feasible criteria, so this learning material can be tested in research.

Then, data collection in this study through observation, documentation, and problemsolving tests. In the data analysis technique researchers used the SPSS version 22 program to conduct normality tests through the Shapiro Wilk test. Hypothesis testing uses Mann Whitney $\mathrm{U}$. The decision making of the hypothesis in this study was if the significance value were smaller than $\alpha(0.05)$ then ha was accepted, meaning that there were differences in student learning outcomes between the experimental group and the control group. Increasing problem-solving ability was calculated using the Normalized Gain (N-Gain) statistical test based on the results of the pretest and posttest with the provisions of the N-Gain criteria according to Hake [9].

\section{Results}

Student learning outcomes were seen from the average scores of the pretest and posttest for the experimental group and the control group in the problem-solving test. Data from students' 
problem-solving tests were carried out statistical tests in the form of normality, homogeneity, and differences in mean learning outcomes between the experimental and control groups. The results of statistical tests on pretest data in the experimental and control groups were shown in Table 2. Based on the results of the statistical test in Table 2 shows that there was no difference in the mean value of the students' problem-solving ability pretest between the experimental group and the control group.

Tabel 2. The Results of Statistical Tests on Pretest Data of Problem Solving.

\begin{tabular}{lll}
\hline Data & $\begin{array}{l}\text { Group } \\
\text { Experiment }\end{array}$ & Control \\
\hline Number of Students & 36 & 36 \\
Pretest Score & 37.90 & 38.10 \\
Normality & 0.20 & 0.06 \\
Mann Whitney- $U$ & 0.945 & \\
\hline
\end{tabular}

Thus, to see the increase in students' problem-solving ability in each group, then analysis was carried out on the posttest value of problem-solving ability. Table 3 shows that the posttest problem-solving abilities of the experimental group students and the control group. Based on the test results of the mean difference in posttest values of students' problem-solving abilities indicate that the significance value of 0,00 was smaller than the significance level $\alpha(0.05)$. It means, there were differences in the mean posttest values of students' problem-solving skills between the experimental groups that use learning materials based on local wisdom of agriculture in Binjai and control groups used student handbook.

The discussion of each component of problem-solving ability was as follows.

Table 3. The Results of Statistical Tests on Posttest Data of Problem Solving.

\begin{tabular}{lll}
\hline Data & $\begin{array}{l}\text { Group } \\
\text { Experiment }\end{array}$ & Control \\
\hline Number of Students & 36 & 36 \\
Posttest Score & 43.90 & 80.10 \\
Normality & 0.00 & 0.11 \\
Mann Whitney- $U$ & 0.00 & \\
\hline
\end{tabular}

Table 4 shows that there were significant differences in the results of the pretest and posttest in the experimental group students, while the control group students did not show any difference between the results of the pretest and posttest. It was because students in the experimental group have been trained continuously to analyze problems by formulating the problems contained in the first component, then with the formulation of problems that have been made by these students, then students were able to connect between the formulation of the problem with the problem actually happened in the management of agriculture in Binjai. Also, with the formulation of the problem at the beginning of the component, helping students become more thorough and systematic in thinking. 
Tabel 4. The Statistical Tests Results of Formulate the problem.

\begin{tabular}{lllll}
\hline \multirow{2}{*}{ Data } & \multicolumn{2}{l}{ Experiment } & Control \\
& Pretest & Posttest & Pretest & Posttest \\
\hline Score & 47.14 & 85.70 & 47.14 & 53.80 \\
Normality & 0.00 & 0.00 & 0.00 & 0.00 \\
Mann & 0.00 & & 0.08 & \\
Whitney U & 0.71 & & 0.07 & \\
N-Gain & 0.71 & & \\
\hline
\end{tabular}

Furthermore, the statistical test result to examine the problem component in the experimental and control groups were shown in Table 5.

Tabel 5. The Statistical Tests Results to Examine the Problem.

\begin{tabular}{lllll}
\hline \multirow{2}{*}{ Data } & \multicolumn{2}{l}{ Experiment } & Control \\
& Pretest & Posttest & Pretest & Posttest \\
\hline Score & 33.81 & 84.76 & 34.76 & 51.90 \\
Normality & 0.00 & 0.00 & 0.00 & 0.00 \\
Mann & 0.00 & & 0.00 & \\
Whitney-U & 0.00 & & 0.20 & \\
N-Gain & 0.76 & & 0.00
\end{tabular}

Table 5 shows the differences in the results of the pretest and posttest in each of the experimental and control groups. However, the posttest score in the experimental group students was greater when compared to the posttest score in the control group. It was because students were used to answering questions that refer to indicators to examine the problem. The problem study component was often found by students on several questions in learning materials based on local agricultural wisdom in Binjai, the more often students were trained with questions that lead to the problem study component, the easier it was for students to answer questions at the posttest so that the ability to study problems becomes a component that the biggest increase. Plus that in the actual article text has explained the problems in general, with this, it can facilitate students in analyzing problems and also more directed.

The use of learning materials based on local agricultural wisdom in Binjai during the learning process encourages students to find out natural phenomena that occur in the environment around students. By integrating agricultural management into ecosystem material and environmental change, students can analyze the positive and negative impacts of these activities on the environment. Students were also trained to interpret scientific evidence based on agricultural activities in Binjai and to relate it to the surrounding environmental conditions. Overall, the use of learning materials based on local agricultural wisdom in Binjai greatly helps students to improve their ability to solve problems, especially in the component of studying problems. Also, through learning Biology using learning materials based on local agricultural wisdom in Binjai who practice these skills, it is expected to form students who were skilled at solving problems related to environmental conservation.

Furthermore, the results of the statistical test data of formulating the hypothesis component in the experimental and control groups were shown in Table 6. It shows that there were significant differences between the pretest and posttest scores in the experimental group students, while the control group did not show any difference between the pretest and posttest scores. 
Tabel 6. The Statistical Tests Results of Formulate hypotheses.

\begin{tabular}{lllll}
\hline \multirow{2}{*}{ Data } & \multicolumn{2}{l}{ Experiment } & Control & \\
& Pretest & Posttest & Pretest & Posttest \\
\hline Score & 45.20 & 78.10 & 44.76 & 44.80 \\
Normality & 0.00 & 0.00 & 0.00 & 0.00 \\
Mann & 0.00 & & 0.942 & \\
Whitney-U & & & 0.03 & \\
N-Gain & 0.56 & & 0.03 \\
\hline
\end{tabular}

Environmental problems contained in learning materials ask students to provide allegations if the problem cannot be overcome or resolved. This information was implicit in the exercise so that students only provide allegations that the students think were likely correct. Even though they have been given repeated exercises, the components formulating hypotheses were considered quite difficult for students to answer causing this component to be the component with the lowest increase among other components. This becomes difficult for students because during the learning process in school students were not trained and guided to formulate hypotheses of a problem. In this case, hypothesizing is one component of problem-solving that students must master so students were active in learning and easy to master the lesson. But in fact, an increase in learning outcomes in both the experimental and control groups shows that the component of formulating hypotheses was a component with a low increase.

The use of learning materials by utilizing the environment and local culture in the surrounding area as a learning tool can bridge students to solve environmental problems because they were faced directly with the environment around the student's residence. Besides being able to improve the ability to solve environmental problems, the use of local wisdom-based learning materials can also instill a loving attitude towards the environment. The students' love for the environment will foster the behavior of students' responsibility to preserve the environment and motivate students not to damage the environment.

Last, the results of the statistical test data of a caring attitude towards the environmental component in the experimental and control groups were shown in Table 7. Table 7 shows that there was a greater difference between the mean scores of the post-test in the experimental group compared to the control group. It was because students have been trained in giving decisions to solve a problem, so students were also able to analyze the consequences of the solutions they have provided in solving problems.

Tabel 7. The Statistical Tests Results of Evaluation.

\begin{tabular}{lllll}
\hline \multirow{2}{*}{ Data } & \multicolumn{2}{l}{ Experiment } & Control \\
& Pretest & Posttest & Pretest & Posttest \\
\hline Score & 27.14 & 76.19 & 28.10 & 30.95 \\
Normality & 0.00 & 0.00 & 0.00 & 0.00 \\
Mann & 0.00 & & 0.26 & \\
Whitney-U & 0.00 & & 0.05 & \\
N-Gain & 0.67 & &
\end{tabular}

Figure 1 shows the effectiveness of learning materials based on local wisdom of agriculture in each component. In the experimental group obtained an $\mathrm{N}$-gain value of 0.67 with a medium category, while in the control group obtained an $\mathrm{N}$-gain value of 0.05 with the low category. This means that the increase in learning outcomes in the experimental group using learning 
materials based on local wisdom of agriculture in Binjai was better than the control group that uses school learning materials.

The use of learning materials based on local agricultural wisdom in Binjai during the learning process encourages students to find out natural phenomena that occur in the environment around students. As expressed by Qolbi, et al. [10], states that local culture-based learning is very important to be done to provide contextual learning insights in improving students' problem-solving skills, this is because it connects local culture with students' scientific knowledge. By integrating agricultural management into ecosystem material and environmental change, students can analyze the positive and negative impacts of these activities on the environment. Students were also trained to interpret scientific evidence based on agricultural activities in Binjai and to relate it to the surrounding environmental conditions. Overall, the use of learning materials based on local agricultural wisdom in Binjai greatly helps students to improve their ability to solve problems, especially in the component of studying problems. In addition, through learning Biology using learning materials based on local agricultural wisdom in Binjai who practice these skills, it is expected to form students who were skilled at solving problems related to environmental conservation.

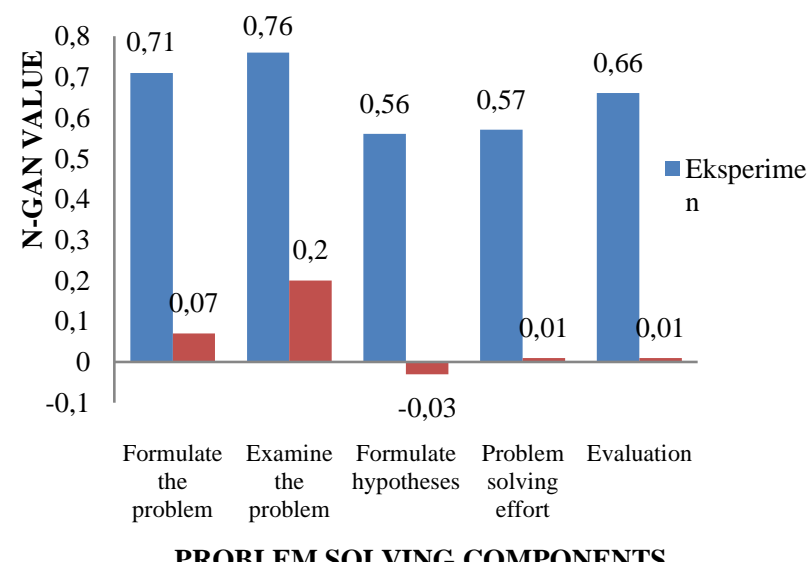

Fig. 1. N-Gain Value of Problem Solving Ability Test.

\section{Conclusion}

Based on the test results on students' problem-solving abilities, the highest component was in the examine the problem with the $\mathrm{N}$-gain value was 0.76 while the lowest component was shown in the formulate hypotheses with the $\mathrm{N}$-gain value was 0.56 . Overall, the $\mathrm{N}$-gain value of the student's problem-solving ability test was obtained at 0.67 with a medium category, meaning that the learning material based on local wisdom of agriculture in Binjai was effective in improving student learning outcomes for environmental literacy. 


\section{References}

[1] Mutiani: IPS dan Pendidikan Lingkungan:Urgensi Pengembangan Sikap Kesadaran Lingkungan Peserta Didik. SOSIO DIDAKTIKA: Social Science Education Journal. Vol. 4, No. 1, pp. 45-53 (2017)

[2] Scholz, C.: Corporate Culture and Strategy: the problem of stategic fit. Long Range Planning. Vol. 20 No. 4, pp. 78-87 (1987)

[3] Ristiana, E., Amin, M., Zubaidah, Heni S. I.: Improving Problem-Solving Ability Through CultureBased Learning Model Of Tudang Sipulung. IOSR Journal of Pharmacy and Biological Sciences (IOSR-JPBS). Vol. 12, No. 3, pp. 11-14 (2017)

[4] Titin: Peningkatan Keterampilan Pemecahan Masalah (Problem Solving) Calon Guru Biologi Melalui Pembelajaran Berbasis Kearifan Lokal. Jurnal Pendidikan Matematika dan IPA, Vol. 9, No. 1 (2018)

[5] Djulia, E.: Peran Budaya Lokal dalam Pembentukan Sains (Studi Naturalistik Sains Siswa Kelompok Budaya Sunda tentang Fotosintesis dan Respirasi Tumbuhan dalam Konteks Sekolah dan Lingkungan Pertanian. (Disertasi). Sekolah Pascasarjana, Universitas Pendidikan Indonesia, Bandung (2005)

[6] Subiantoro, A. W., Ariyanti, N. A., and Sulistyo: Pembelajaran Materi Ekosistem dengan Socioscientific Issue dan Pengaruhnya Terhadap Reflective Judgement Siswa. Jurnal Pendidikan IPA Indonesia (JPII), Vol. 2, No. 1, pp. 41-47 (2013)

[7] Syafii. W., and Yasin, M. R.: Problem Solving Skills and Learning Achievements through ProblemBased Module in learning and learning Biology in High School. Asian Social Science. Vol. 9, No. 12 (2013)

[8] Parmin and Peniati, E.: Pengembangan Modul Matakuliah Strategi Belajar Mengajar IPA Berbasis Hasil Penelitian Pembelajaran. Jurnal Pendidikan IPA Indonesia 1. Vol. 1 (Online) (http://journal.unnes.ac.id/index.php/jpii) (2012)

[9] Hake, R. R.: Analyzing Change/Gain Scores. (Online). Accessed form: http://www.physics.indiana.edu/ sdi/AnalyzingChange-Gain.pdf (1999)

[10] Qolbi, F., Kartimi and Roviati, E.: Penerapan Pembelajaran Berbasis Sains Budaya Lokal Ngarot untuk Meningkatkan Keterampilan Berpikir Kritis Siswa pada Konsep Plantae (Studi Eksperimen Kelas X di SMAN 1 Lohbener). Scientiae Educatia : Jurnal Pendidikan Sains (2016) 